\title{
Property Rights and the Management of Animal Genetic Resources
}

\author{
Simon Anderson and Roberta Centonze
}

2033 K Street, NW, Washington, DC 20006-1002 USA • Tel.: +1-202-862-5600 • Fax: +1-202-467-4439 ifpri@cgiar.org www.ifpri.org

NOTICE: CAPRi Working Papers contain preliminary material and research results, and are circulated prior to a full peer review in order to stimulate discussion and critical comment. It is expected that most CAPRi Working Papers will eventually be published in some other form, and that their content may also be revised.

Copyright 2005, International Food Policy Research Institute. All rights reserved. Sections of this material may be reproduced for personal and not-for-profit use without the express written permission of but with acknowledgment to IFPRI. To reproduce the material contained herein for profit or commercial use requires express written permission. To obtain permission, contact the Communications Division at ifpri-copyright@cgiar.org 


\begin{abstract}
Genetic erosion in animal genetic resources (AnGR) is of concern where livelihoods of the poor are affected and option values for society are being lost. The poor often live in marginal areas and their livestock maintain adaptive characteristics. However, processes leading to genetic erosion do not precipitate adaptation through natural selection.
\end{abstract}

This paper explores how local property rights systems in poor communities for AnGR are organized. The dynamism and dialectical aspects of these systems are considered and the impact of their breakdown assessed in terms of AnGR diversity.

The conservation of AnGR option values through livestock husbandry by the poor is a hitherto unrecognized and unrewarded service to society.

Keywords: animal genetic resource; property rights; poverty; pastoralists; option value; India; South Asia 


\section{TABLE OF CONTENTS}

1. Introduction 1

2. Animal Genetic Resources Erosion—A Problem Statement 2

3. The Option Values of Animal Genetic Resources 4

4. Loss of Animal Genetic Resources from a Property Rights Perspective 7

5. Local Rules and Institutions for Animal Genetic Resources: Evidence from India 11

6. Participatory Approaches for a Pro-Poor Management of Animal Genetic Resources 22

7. Final Remarks 25

$\begin{array}{ll}\text { References } & 27\end{array}$ 


\title{
Property Rights and the Management of Animal Genetic Resources
}

\author{
Simon Anderson ${ }^{1}$ and Roberta Centonze ${ }^{2}$
}

\section{INTRODUCTION}

This paper seeks to show the relevance of property rights regimes to understanding the causes behind the differential (and concerning) rates of erosion in animal genetic resources (AnGR). Critical issues related to AnGR conservation and sustainable use are discussed from a pro-poor perspective. These issues include the discrepancies in attribution of value to AnGR by livestock keepers and those involved in conservation policy making. Opportunities for in situ conservation are explored from a people-centered approach considering the management of AnGR in terms of local institutions and rules in use. In particular, the Collective Action and Property Rights model has been utilized with respect to AnGR management at the local level. A synthesis of experiences that used participatory approaches to analyze local institutions provides interesting insights into the understanding of local realities and the elaboration of policy tools. The fieldwork was mainly carried out in North West India, (Rajasthan, Pali district) and is supported by the findings of research in Yucatan and Chiapas states of Southeast Mexico.

The first section of the paper sets out how differential rates of erosion of AnGR are prejudicing the current livelihood strategies of poor livestock keepers. The

\footnotetext{
${ }^{1}$ Central Research Department, Department for International Development, Abercrombie House, Eaglesham Road, East Kilbride, Glasgow G75 8EA, UK. Phone: +44 (0)1355 843793 Email: SAnderson@dfid.gov.uk

${ }^{2}$ Corresponding author, Dipartimento di Economia e Ingegneria Agrarie Facoltà di Agraria Università di Bologna, Viale G. Fanin 50, 40100 Bologna, Italy

Phone and fax: +39 (0) 51490539 Email: roberta.centonze@fastwebnet.it
} 
significance of the depletion of AnGR important as a reservoir of adaptive traits in terms of option values (i.e. future potential unknown benefits) for the wider society is also discussed. The next section explores the problem AnGR loss poses for pro-poor development. Explanation of the differential rates of genetic erosion in AnGR is then approached from a property rights perspective. The complexities of local property rights systems for AnGR are illustrated with examples of Raika pastoralists in North West India. Such systems are under threat of erosion that could result in significant loss of AnGR. Processes of collective action by livestock keepers and those interested in conservation of AnGR from a pro-poor perspective are then outlined. The final remarks draw wider lessons about the need to integrate local and national property rights systems in order to achieve more sustainable management of AnGR.

\section{ANIMAL GENETIC RESOURCES EROSION-A PROBLEM STATEMENT}

Sixteen per cent of AnGR has been lost over the last 100 years (Hall \& Ruane 1993) and currently breeds at risk comprise approximately one-third of all remaining breeds, 22 percent of mammals and 48 percent of avian species (FAO 2000).

These rates of AnGR loss are differential. Developing countries have notably higher rates than others and socio-political, economic and agro-ecological determinants are leading to the most dramatic genetic erosion of AnGR important to the livelihoods of many of the world's poor (Anderson 2003). As an estimated 1.96 billion people rely on livestock to supply part or their entire daily needs, the scale of the problem AnGR loss poses for pro-poor development can be appreciated. The poor need AnGR suitable for their purposes yet traditional pastoral groups are often accused of clinging to an outdated 
way of life and representing drains on national economies (Mendelsohn 2003). A contrary view, explored here, is that the contribution of pastoral societies to the maintenance of biodiversity in domesticated animals, and their role in keeping otherwise barren tracts of land habitable, should be estimated and then rewarded.

The AnGR kept by poor livestock keepers in marginal areas have high diversity of adaptive genetic characteristics (tolerant of high temperatures, resistant to disease vectors and challenges). Yet these AnGR are most at risk of genetic erosion (Anderson 2004). In part this is due to the rising demand for animal products in developing countries causing structural changes in land use through intensification of mixed farming systems. Genotype-environment interactions mean that animals bred for intensive production systems are often not appropriate for the production systems the poor utilize (Anderson 2003). Indeed, this shift from grazing-based to industrial livestock production systems brings disadvantages in terms of genetic conservation and environmental impacts. Externalities are caused both in terms of genetic resource loss and environmental damage. Hence, the global livestock industry faces the challenge of developing ways of allowing economic development to benefit the poor that utilize, and thereby maintain, AnGR (Blackburn, et al. 1998). Recognition of the significance of adaptive characteristics demonstrates the significant potential value for society of the AnGR kept by the poor. The option of being able to exploit AnGR diversity becomes better appreciated as technological developments allow the identification, characterization and exploitation of genetic material. Because of this, AnGR are likely to be valued more in the future due to their adaptability to local ecosystems, their value for conservation, and their role vis-à-vis restoration of ecosystems (van der Zijpp, nd). 


\section{THE OPTION VALUES OF ANIMAL GENETIC RESOURCES}

The loss of hardy breeds and their corresponding adaptive genetic traits means a reduction in the range of biophysical environments that can be utilized by humankind. To local users, the loss of genetic resources is a loss of entitlements in terms of material resources (for productive purposes), which may also lead to loss of the knowledge required to husband such resources.

One of the components of the economic value generated by AnGR, and maintained by those that husband the livestock, is termed "option value."3 Option values refer to the benefit derived from safeguarding an asset for the option of using it at a future date. It is a kind of insurance value against the occurrence of, for example, a disease, drought or climate change. The opportunity provided by locally adapted livestock for the production of manure, meat, wool and milk, and the provision of work, transport and social functions in harsh environments represents an entitlement (endowment) of local people. ${ }^{4}$ Furthermore, in the eventuality of a wider market demand for the specific traits, the livestock represent an option value for wider society. ${ }^{5}$ Option value can then be projected into the future either on a global scale or on a local scale as part of the entitlements of a given household or population.

The option value for a given breed increases with the uniqueness of its characteristics, with the genetic distance of its traits from others,' and with the rarity of

\footnotetext{
${ }^{3}$ A review on the different components of total economic value for AnGR is provided by Drucker et al., (2001).

${ }^{4}$ This consideration finds its basis in Sen (1987).

${ }^{5}$ See the definition of option value in Pearce and Moran (1994).
} 
the breed itself. ${ }^{6}$ As already stated, the ability to utilize genetic traits is consequence of technological development. Among traditional livestock keeping communities, a breed is valued according not only to its market value but also for the beliefs and traditions which it is bounded to. Such traditions may derive from the acknowledged opportunity to maintain as many options as possible in a single productive unit or in a cluster of interdependent units. For example, the Raika pastoralists of Rajasthan have a single term, independent of species, for animals used for reproductive purposes - Saand. All saand (sheep, goats, cattle, buffalo, and camels) have religious value and are often protected by rules preventing sale or being slaughtered, in order to maintain the 'value' of the productive unit. The productive unit can be a single household, in case of sheep and goats, or the whole village, in case of cattle and buffalo. Saand can be exchanged, but not for direct monetary profit. However, the idea of profit is not totally excluded in the dynamic development of local property rights rules (Centonze 2003). Similar cultural value is assigned to local Chiapas (Southeast Mexico) sheep breeds by Tzotzil indigenous shepherdesses, and this impacts upon ownership duties and property rights, and precludes the consumption of sheep meat.

In subsistence systems choices related to herd composition (species, breeds, age and sex categories of livestock) may be driven by the purpose of efficient production, which can include minimizing risk. The following section gives examples from India of how different species and breeds of animals assume different values in a flock/herd composition.

\footnotetext{
${ }^{6}$ Mc Neely (1996) describes the criteria used by IUCN (International Union for Nature Conservation) to establish the importance of plant and animal species. Henson (1992) provides thresholds for judging the relative status of vulnerability to extinction of animal populations.
} 


\section{(a) Option value for species and breed diversity in India}

Research with the Raika ethnic group in Rajasthan North West India, has shown that, at the local level, the option value of a breed or of a species is a kind of insurance value against the occurrence of, for example, a new disease or drought (Centonze 2003). Raika are specialist sheep breeders. However, their flocks often include proportions of goats (less than a third). Over the last few years the shrinkage in land area available to the pastoralists is causing a shift towards goat production, and away from sheep, due to the goats' better foraging and browsing ability.

Keeping mixed herds of sheep and goats has several advantages due to the complementarities between the species in the agro-ecosystem, given the ways the Raika manage natural resources. While sheep milk is sold every morning at the dairy collection points, goats' milk is used for household consumption. Goat meat is also preferred by the Raika and is highly valued for religious and ceremonial purposes. Goat meat achieves a higher market price than sheep meat and sales are an important source of Raika household income especially during the dry season.

Furthermore, with respect to species complementarities in the herd, goats can serve as wet nurses for lambs whose mothers have died. Goats are able to lead the herd helping to control the sheep. Goats are very well adapted to the ecosystem, they are more resistant to diseases than sheep and during the dry season they can browse trees and bushes. On the other hand, sheep have the advantage of producing wool, in addition to milk and meat, they are shorn up to three times per year, and sheep dung is considered of better quality than goats.'

Geerlings (2001) recorded quantitative information about breed diversity in the Raika community. Breed diversity in the herd does not depend on herd size. Small herds 
were observed with more than five different breeds whilst some large herds had only one or two breeds and vice versa. Of all the breeds, the so-called Boti breed was highest both in absolute number per flock as well as numbers of owning households. The Boti breed was present in 72 per cent of flocks, while the so-called Bhagli sheep breed was present in 42 per cent of flocks.

Boti is also called desi which means local and according to the FAO classification it corresponds to the Marwari breed (FAO 2000). The Boti breed is better able than other sheep to survive deficiencies in fodder and water availability, although it is relatively less productive than other breeds under good conditions. Government incentives to introduce other breeds to increase production have led to a decline in the proportion of Boti sheep. However, when a bad year is expected (monsoon failure), people still prefer to breed or cross breed their females with Boti rams. On the other hand, in better years people prefer breeding with Bhagli or other more productive breeds. This way of utilizing animal diversity indicates the local people's perception of AnGR option value.

\section{LOSS OF ANIMAL GENETIC RESOURCES FROM A PROPERTY RIGHTS PERSPECTIVE}

Given the values of AnGR to local people and society, why is this differential loss of adaptive AnGR happening? Meinzen-Dick and Pradhan (2002) state that missing or poorly defined property regimes can cause inefficiencies in markets through the production of externalities. Pearce and Moran (1994) cite market failures as one of the main causes of (agricultural) biodiversity loss. When the activity of genetic resource conservation generates economic values that are not captured in the market place, the result of this 'failure' is a distortion where the incentives are against genetic resources 
conservation and in favor of the economic activities that erode such resources. Such outcomes are associated with market, intervention and/ or global appropriation failures.

To explore further the differential loss of livestock genetic diversity, an understanding of AnGR as property resources and the rights regimes under which these resources are owned is required.

Property is defined by Bromley (1991: 2) as a 'benefit stream' that the state will agree to protect through the assignment of duty to others who may cover or somehow interfere with the benefit stream. Property rights convey the right to benefit or prejudice oneself or another (Demsetz 1967) and they affect the formation of peoples' expectations of each other. Expectations are expressed in the laws, customs and mores of a society. Property rights influence the way a resource is invested, managed, exchanged within and between societies. Each market transaction represents an exchange of two bundles of property rights. According to Demsetz (1967), the value of the rights determines the value of what is exchanged. On the other hand, the value of the resource exchanged determines which kind of rights is applied to it (Bromley 1991, Bromley \& Cernea 1989). This is because transaction and administrative costs increase as soon as the property regimes become stricter. These two views look at property rights institutions respectively as cause, or effects of changes in the appreciation and management of resources.

Thus the institutional environment and the technological level are crucial to the management of available resources. In particular, initiatives for conservation and sustainable use of AnGR depend on the values and the functions that are attributed to the resource itself. Any change in property rights requires re-adjustment of other components of the socio-economic system. A series of dialectical processes start, dynamic 
equilibrium positions are gained and abandoned (Wang 2001). These mechanisms produce new costs and benefits to different agents. How the externalities produced are redistributed amongst the stakeholders will depend on the nature of the rules, of the resources and of the community. The system will adjust through changes in values, mores, laws and technologies (Norgaard 1994). The perception of a resource's value, as well as the interest in exerting property rights over it, is dependent on the knowledge about the resource itself. As soon as new knowledge arises about a specific resource, new property rights may emerge due to interacting agents desiring to re-arrange cost-benefit options (Bromley 1991). For example, the interest that different stakeholders have to exercise property rights over a certain breed or eco-type of livestock changes as the value of the breed's unique genetic material is understood and recognized.

Biotechnology has shifted the public attention on previously neglected resources by revealing genetic properties and information relevant at a technological level (Dutfield 2000). Often the properties at issue are not ignored by indigenous population, but simply known under a different code.

AnGR provide public and private goods and services. Their values are derived from the private functions for the household plus the functions of public interest (Drucker et al. 2001). Disparities arise in the appreciation of value in part due to the different technological tools used to access to the resource: paradoxically the global society (macro level) explores the micro structure (genotype - alleles, nucleotides etc.) while households or local communities have been interested in macro structure (phenotype - adaptive traits, productive performance, appearance etc). 
However, these differences in ways of appreciating value do not necessarily imply an incompatibility of objectives. On the contrary, it includes the potential for combined actions or partnerships for in situ and ex situ genetic resources management. At the local level, AnGR are part of the assets portfolio of a household, and, depending on the entire portfolio options, AnGR are more or less crucial in the livelihood strategies towards a sustainable well being (Dorward 2005). At the global level where, given that the entire portfolio of AnGR endowments is decreasing and many unknowns exist in terms of requirements for AnGR, it has become crucial to maintain diversity at, at least, it's present status (The Crucible II Group 2002).

To establish sustainable AnGR management regimes capable of making contributions to improving the livelihoods of poor livestock keepers' greater understanding is required of:

- The ways local communities organize ownership, access and management of AnGR;

- The enabling environment required for local people to best maintain and enhance AnGR.

Once a) and b) are better understood, sustainable AnGR management regimes should provide the means whereby local, national and international property rights systems are integrated to provide security of assets for the poor and processes of benefit sharing from the maintenance and realization of the option values of AnGR managed by the poor. 


\section{LOCAL RULES AND INSTITUTIONS FOR ANIMAL GENETIC RESOURCES: EVIDENCE FROM INDIA}

The importance of local norms for natural resources management (creating sui generis regulations) depends upon 'four main uncertainty variables: ecological uncertainties, livelihood uncertainties, social and political uncertainties, and knowledge uncertainties' (Meinzen-Dick \& Pradhan 2002: 8). Solving uncertainties and acquiring more knowledge about the context allows greater control reducing one's vulnerability. Local norms and customs increase in number and peculiarity through collective attempts to reduce uncertainties. A closely woven net of social interdependencies creates reciprocal insurance against external variables.

Local institutions define the rules of access to complementary goods and services for livestock production, such as land and water, thus shaping the productive patterns in a village community. Consequently, depending on the social arrangements for animals, land, water ownership and access rights, contributions that livestock provide to different livelihoods vary.

Systems of AnGR ownership can be described and analyzed according to the Institutional Analysis and Development framework ${ }^{7}$ (Ostrom 1985). A synthesis of the

\footnotetext{
${ }^{7}$ Formulating elements of institutional analysis are:

Boundary rules set the entry, exit, and domain conditions for individual participants.

Position rules establish positions, specify procedures by which participants are assigned into positions, and define who has control over tenure in a position.

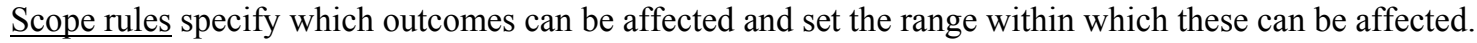
Authority rules prescribe which positions are authorised to take which sets of actions and how a series of actions are ordered, processed, and terminated.

Information rules affect the information individuals have about the structure of the situation by establishing information channels, stating the conditions when they are to be open or closed, creating an official language, and prescribing how evidence is to be processed.

Aggregation rules affect control by prescribing the formulae for weighting individual choices and calculating collective choices at different points in a process.

Payoff rules prescribe how benefits and costs are to be distributed to participants in positions given their actions and those of others.
} 
rules in force for animal ownership in the Raika pastoralist community in Rajasthan

North West India is summarized in Table 1.

Table 1--Property rights rules for animal genetic resources of the Raika pastoralists in Rajasthan, North West India

\begin{abstract}
Property right Example from Raika AnGR management systems in Rajasthan rules

Boundary rules Sale of female animals out of the Raika caste prohibited. The rule filters access and avoids outward flows. Although declared as religious, this norm has political and economic aspects. Members of other communities are prevented from starting the activity of animal breeding, thus not exceeding the use of common property resources (gochar, oran). Females are maintained inside the flock as renewable production resources preventing the financial collapse in emergency situations
\end{abstract}

Access rules Being able to gain access to breeding male animals depends on community boundaries and personal relationships

Position rules The owner livestock may dedicate the animal to God, and define who has access to the animal (borrowing). The owner has to ensure good condition to the saand till natural death

Scope rules Female small ruminants, holy males and any cattle cannot be slaughtered. Further more, no money can be gained from the saand through the exploitation providing breeding services.

Aggregation Collective access and use of genetic resources requires the livestock and payoff breeders to contribute to feeding (ghee, oils, sweets and fodder)

rules

Each herder, depending on his access to labor and capital, will adjust the number of animals grazed in the gochar

Periods of resource appropriation with respect to small and large ruminants accessing common land. Small ruminants, more destructive of the available fodder, are allowed in only after the larger ones

Communal mechanisms of solidarity towards herders in need

'Common bull' and 'buffalo bull' purchased by all the villagers for their religious value 


\section{Table 1--Property rights rules for animal genetic resources of the Raika pastoralists in Rajasthan, North West India (Continued)}

The activity of grazing is also organized in common for all the village cattle and buffaloes. This institution is called 'four legs' and it works during the rainy season when the animals need to be kept out of the agricultural fields. It relies on a 'village herder' paid by all cow and buffalo owners

'Gowsala' a collective shelter where non-productive and productive cattle are brought at an inter-village level during drought

Authority and information rules

Selection mechanisms of AnGR vary across species. For small ruminants the choice is personal and may benefit from informal advice. However, the purchase of a bull is a village matter and the best knowledge available in the community is identified and utilized

Source: Authors' own elaboration according to the clusters of rules indicated in Ostrom (1985)

Property rights for natural resources are dynamic and divided into sub-rights, according to agents' position in a community (Meinzen-Dick \& Prandhan 2002). Ostrom and colleagues distinguish between ownership and use rights (Ostrom et al. 1994). Ownership of resources brings related duties, and privilege of access carries related responsibilities (Bromley 1991). In the case study considered, AnGR are subject to different rights and mores from which the idea of property can be disaggregated in different ways. Firstly, the right to make decisions related to the selection of animals, which may involve purchase, loan, exchange etc., at the moment of breeding. Secondly, the right to make and implement husbandry decisions central to the rearing of the animal. Thirdly, the right to prescribe slaughter (that may be reserved to God only and if so means the duty/ responsibility for avoiding and preventing any harm to the animal is left to the human owner).

The way AnGR are managed in low external input systems is also dependent upon the property rights of the livestock owners over the resources required in the rearing 
process. In Rajasthan, North West India, property rights for animals and land include: common land resources - holy land (oran) and grazing land (gochar); private land resources - agricultural land; common livestock resources - village bull and village malebuffaloes (their shelters are also common property); and, private livestock resources cows and female-buffaloes, small ruminants and other livestock.

Land suitable for cropping is owned by Rajput (a higher caste) people, who normally cultivate it once or twice a year. Livestock keepers have access to the land during post-harvest and fallow periods. Thus, although a hierarchical disparity between rights exists, a kind of multiple tenure, as defined by Bromley and Sjiaastad (2000: 13), applies also to private land.

When local pastures, either private land or common areas are not sufficient for the number of animals of a given area, livestock keepers migrate towards Madhya Pradesh or Uttar Pradesh forests, depending on the water availability they may or may not decide to come back to the village during the rainy season. Since $1974^{8}$, access to common land (gochar) has been threatened through the establishment of nursery areas by the Forest Department. Environmental legislation, combined with corrupt mechanisms in the forest department, burdens the pastoralists' production system. Consequently, the pressure from pastoralists on farmers is becoming greater due to the drastic decreases in fodder sources (Agrawal 1992).

Animals grazing on common land not only grow and produce milk and wool, but they also transfer nutrients from the grazing area to where they are kept at night and dung can be collected for private use. Such transfers also involve changes from low to high quality and value, and public to private resources. At the village level, livestock keepers

${ }^{8}$ cfr. Government of India (1974). 
have the duty to provide the landowners all the dung collected in the corrals. Landowners have the right of first access over the village dung.

However, the dependence of farmers on pastoralists has declined due to the formers' greater use of chemical fertilizers. Moreover, the intensification of cropping systems reduces the fallow periods and thus the access to the land (Agrawal 1992).

Environmental policies aimed apparently at natural resource conservation as well as the fading reciprocity between farmers and livestock keepers are challenging the sustainability of AnGR management in such a marginal environment.

\section{COMMON AND PRIVATE LIVESTOCK MANAGEMENT}

Property rights for breeding animals vary by location and by animal type. It is often the case that breeding males are either managed as a common resource or are managed by individuals, but access is allowed subject to local property rights rules. Females are often under private ownership. Where grazing of common land resources can be organized, animals owned by different individuals are managed (and bred) as a single group.

The village bull 'godha,' and the village buffalo bull 'padha,' are traditional institutions in Rajasthan. These animals are common property of all villagers and not dependent on their ownership of cows. All the villagers contribute to purchase bulls. Good bulls are normally too expensive to be purchased by a single family, especially those of preferred breeds. All villagers desire to have access to a good breed both for production and because good animals give status to the villagers. The right of use of these males for breeding is unconditional for all the villagers. Everybody contributes to feed and health care as necessary. This practice is still intact due the holiness of the bulls. 
Access for mating is allowed to outsiders who pay in kind or in money for fodder or sweets for the bull. The payment may not be required if the person is poor.

In contrast all the female cattle, buffalo and small ruminants are private goods. The mechanisms of sharing ram or buck goats are conditioned by personal relationships. Costs for these animals are born by the owners (purchase, feeding, health care). Benefits are shared among owners and users (the reproductive resource is lent to other herders). Responsibilities for the maintenance of the resource are assigned to each user who temporarily contributes to feeding expenses.

An example of a private AnGR managed in such a way that provides benefit to the wider community is the amar. In the Godwar area, an amar is normally the best male in the herd and it is used for reproductive purposes. Any amar is devoted to Shiva and cannot be sold, nor slaughtered. Having an amar sheep contributes to the social status of Raika. ${ }^{9}$ Thus, the owner keeps an amar until its natural death as religious norms prevent its slaughter.

Normally, the Raika control inbreeding by selling males after two or three years. Amars are often lent for free for a period of two to three years to other Raika, then returned to the original owner. The borrower has the privilege to use the amar and is responsible for its health.

\section{COLLECTIVE MANAGEMENT OF PRIVATE LIVESTOCK}

The chopa system is a form of collective action to manage private and common resources. The chopa (four legs) entails gathering all cattle and buffaloes in the village, private and common ones, in the accria (village main square) and then taking them for

\footnotetext{
${ }^{9}$ For an exhaustive analysis of the situation, see Robbins (2000)
} 
grazing. In the late afternoon all livestock is brought back to the accria. The chopa is normally managed by a gwal or gori (village herder) who is the person in charge of taking the animals to the nearby pastures and looking after them during the day until evening. The seasonality of activity for the chopa system goes in parallel to the agricultural cycle. ${ }^{10}$ Every village needs a gwal for 3 to 10 months per year depending on rain and/ or irrigation availability. The gwal belongs normally to the Raika community. Raikas are defined as 'the best herders' due to their knowledge of animal health care. The gwal is paid by the cow and buffalo owners in kind or money. The price for the buffaloes is normally higher due the relative difficulty in herding them. ${ }^{11}$ The responsibility of finding a gwal is that of the village's Raika peoples. They have to find somebody to take care of the livestock. If the payment is low due to a small village herd, the Raika normally establish a rotation of herding duty.

Another kind of collective agreement for AnGR management is the collective shelter, called gowsala, where non productive cattle and productive ones are brought at an inter-village level, especially in emergency situations (Rathore \& Köhler-Rollefson 2001). The gowsala are open also to other holy animals such as rams and bucks (amar). This activity is organized by Jainists (religious group) and the maintenance of the animals is financially supported by the government.

\footnotetext{
${ }^{10}$ Rainy season: time for cropping so that the land is occupied by crops - animals excluded. The chopa system starts in order to organise the animals to graze on common areas instead of grazing on the fields. Winter: land may or may be not cropped depending on the abundance of water received during the monsoon. Summer: no chopa because the land is left fallow due to water scarcity. Use of private land for grazing.

${ }^{11}$ The gwal is paid $3 \mathrm{~kg}$ of wheat per month per buffalo and $2 \mathrm{~kg}$ per cow.
} 


\section{COLLECTIVE ACTION AND PROPERTY RIGHTS FRAMEWORK}

Olson stated that (1965:2) “[ ...] unless the number of individuals is quite small, or unless there is coercion or some other special device to make individuals act in their common interest, rational, self interested individuals will not act to achieve their common or group interest." On the other hand, Ostrom (1990) points out in her research that in situations where resource users come into regular contact and are able to communicate, negotiate, observe, and learn to predict the actions of others, co-operation, instead of free riding, may be possible. Wade (1988) makes a similar point. Such conditions can be found where resources have few users who have the opportunity to develop trust as well as to monitor each other's behavior.

In order to verify Ostrom's hypothesis about self-governing strategies of cooperation in management strategies for sustainable use of AnGR, we differentiate management activities by two dimensions: their time frames and spatial scales, borrowing an adaptation of the Collective Action and Property Rights (CAPRi - CGIAR Systemwide Program of Collative Action and Property Rights) conceptual framework (Knox et al. 2001, see Figure 1) and applying it to the pastoral system of Raika. 
Figure 1-- Animal Genetic Resources management by Raika of Rajasthan through the prism of the CAPRi framework
Low
Tenure Security
High

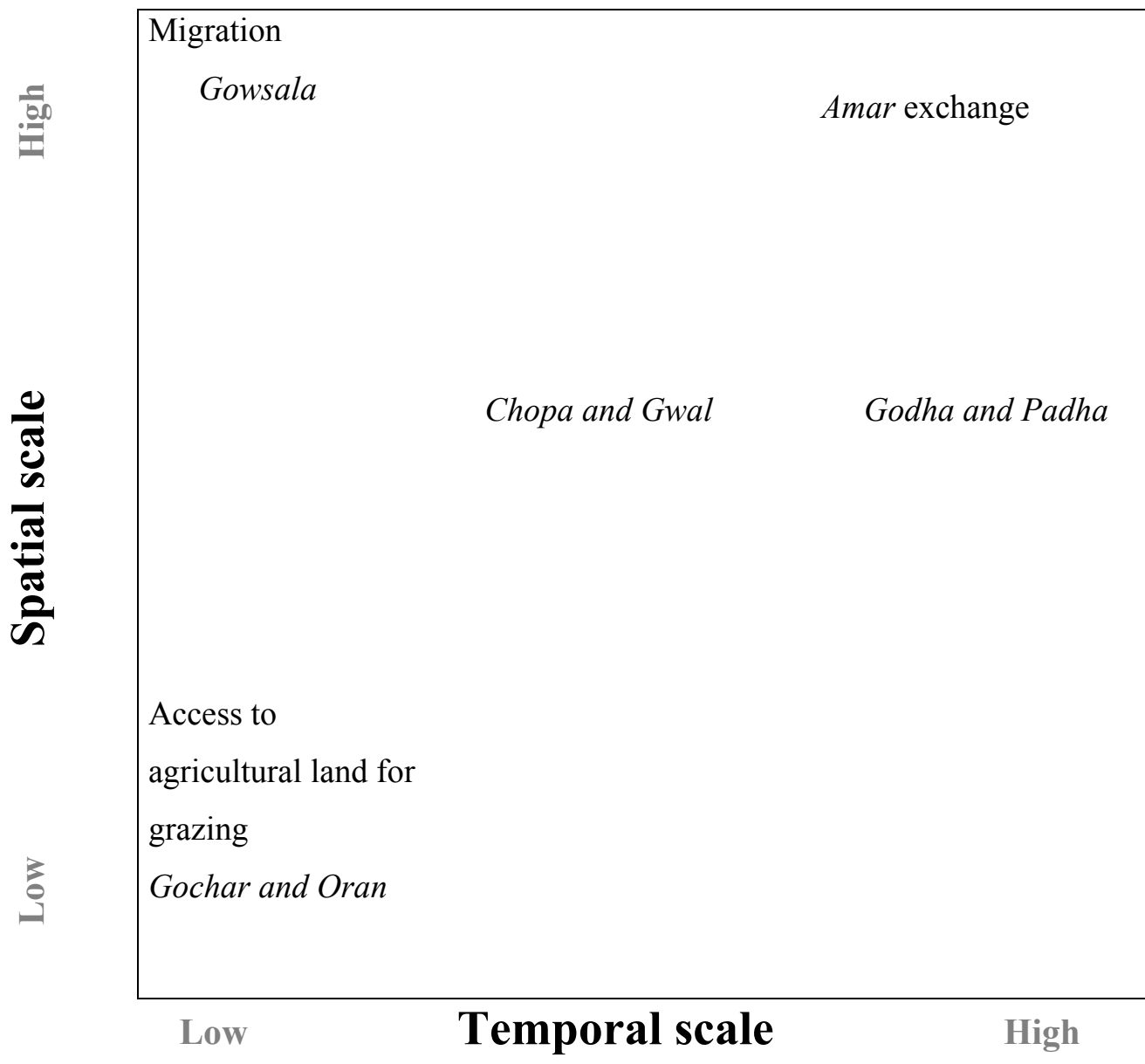

Source: Authors' own elaboration adapted from the framework by Knox et al.2001)

This conceptual frame allows us to highlight the influence of the degree of security of access to land, either common or private, over the activities chosen by livestock keepers to manage AnGR more or less collectively. Specifically, we have considered that all the institutions described represent a 'collective action' since they are norms, created and agreed by all the local stakeholders. All of them assure a certain degree of security of access to the different resources (land, fodder, AnGR). Furthermore, 
shared property rights to AnGR indirectly affect the maintenance of access right to common pastures.

Some institutions refer to the village level (gochar, oran, godha and padha), others extend to an inter-village area (migration); some refer to the Raika community (amar exchange), others involve the local community as a whole (gowsala). With respect to time, some activities are seasonal, others annual, others an investment of more than one year. The different practices described above are plotted in Figure 1 (according to their spatial and temporal characteristics). The practice of amar exchange is carried out over the long term (exchanged for two, three years and giving progeny), and requires a high degree of spatial co-ordination that involves the Raika community and reaches beyond the village level. By contrast, the village bull and buffalo male (godha and padha) institutions interest the single village, yet investment is continuous and long-term. The gwal (cow herder) is normally recruited at a village level although in some cases two villages can join herds and thus collective action needs to extend over village boundaries. The gwal activity for the chopa system is seasonal.

The opportunity to send animals to the common shelter (gowsala) is utilized at an inter-village level and possibly involves all castes. The recourse to gowsala is seasonal but may increase with the level of insecurity of access to land, water and fodder sources that may compromise the livestock keeping activity.

Migration involves a large spatial scale and a seasonal time scale. It is the extreme solution for a Raika family or group of families when a severe resource scarcity occurs at the local level. This happens either due to lack of access rights to private or common land at the village level. Since Raikas do not own land it may happen either that landowners 
practice intensive agriculture and forbid access to land not having fallow periods, or environmental legislation is very restrictive even over village resources such as oran and gochar setting plant nursery for some species conservation. Another limiting factor can be climatic determinants such as extreme drought. Migration may include co-ordination between migrants and sedentary people along the migration route, although incidents and

forms of intolerance are not rare. Above all, migration requires a good level of security of access to some forest land which is the main source of fodder. A lack of such certainty would force livestock keepers to abandon the activity.

The CAPRi framework allows an initial assessment of the needs for and possible effects of different policy interventions that influence access to resources and social relations, and may be used to identify factors necessary to facilitate a more sustainable management of AnGR at the local level.

\section{DYNAMIC AND DIALECTICAL ASPECTS OF COLLECTIVE ACTION AND PROPERTY RIGHTS FOR ANIMAL GENETIC RESOURCES}

Local property rights for AnGR are dynamic and dialectical. The dynamism refers to the temporal dimension of changes and adaptations; the dialectic includes interrelations among coexistent antithetic institutions and stakeholders. In Rajasthan, AnGR are conceived as private goods but are also included in situations of 'multiple tenure.'

Rights of use of land and multiple tenure systems are crucial. Pastoralists will not continue their traditional livestock keeping activities when the mechanisms for land access and tenure security are fading, leading to a foreshortening of fallow periods of cultivated land, less access to forest, and less access to commons (Agrawal 1999). Indeed, as already pointed out, agricultural intensification as well as environmental 
degradation and legislation are causing greater and greater difficulties for the activities of pastoralists either as sedentary or migratory groups.

In Rajasthan it has been observed that, with respect to the status of AnGR, economic factors are prevailing over socio-cultural ones. The common bull (godha) has always had an important role in the community. However, as the economic returns from buffalo bull keeping have increased; private ownership of buffalo bulls has become widespread, representing a good business for some farmers. The payment is 100 rupees per successful mating and the activity lacks of any religious significance.

The amar used to be exchanged within the Raika community. Although still valid, this rule is sometimes broken and the amar are lent to non-Raika in return for monetary compensation.

\section{PARTICIPATORY APPROACHES FOR A PRO-POOR MANAGEMENT OF ANIMAL GENETIC RESOURCES}

Research on genetic erosion of AnGR in different continents has shown that social marginalization and poverty reduce access to resources important to the sustainable management of AnGR (Anderson 2004). Poor households often take decisions that reduce AnGR diversity based on short-term livelihood priorities, rather than emphasizing longer-term aspects of AnGR access and improvement strategies. This will continue to be the case until incentives are provided, or benefits accrue, to those involved in activities that conserve AnGR. There are important genetic and socio-economic reasons why AnGR should be conserved 'in-situ.' Firstly, adaptive traits are best maintained through processes of natural selection brought about by exposing AnGR to changes in local 
environments. Second, a greater set of benefits should accrue to those directly involved in the conservation activities.

In situ conservation can be distinguished into at least two different approaches. External stakeholders such as national government agencies interested in conservation, environmental NGOs, private organizations like industry, scientific and commercial enterprises maintain an approach to conservation of genetic resources that may be termed resource-centered, while local stakeholders like livestock keepers, farmers or their associations aiming at a more immediate utilization of genetic resources put their own livelihoods first, through an approach that may be termed 'people-centered.'

Only where investment in social organization by and within marginalized livestock keeper groups can provide benefits in terms of more sustainable AnGR management and genetic improvement, equitable access to the resources and livelihood improvements, in situ conservation activities can emerge and be recommended as sustainable solutions.

The following two examples from Mexico highlight the possibilities. Investment in the human and social capital in Mayan communities, in Southeast Mexico, led to the re-valuation of plants (local legume varieties) and AnGR (a local pig breed). Whilst the processes that targeted plant and animal genetic resources were enabled by outsiders, aspects of social organization favored the conservation of the local pig breed and a more non-exclusive sharing of benefits. Firstly, a non-cash transfer system was customary for the payment of mating service whereby the owner of the boar takes one of the resulting litter. Thus, only successful mating was paid for and even owners without money could afford to mate their animals. Secondly, pigs and pig products were traded locally 
following a traditional system of equitable allocation of sale days across households. This meant that competition for sales opportunities between pig keepers was minimized. Thirdly, most pig keepers were women and they demonstrated more willingness to share ideas of improved pig keeping, than the men involved in crop innovations who tended to covet information. Interestingly, in many cases the women and men were from the same households (Anderson et al. 2002).

The success of one of the few cases of genuinely participatory AnGR improvement is due, at least in part, to the recognition and respect of local property rights. In Chiapas, Mexico, ethno-veterinarians have enlisted the expertise of Tzotzil shepherdesses in a genetic improvement program of three local sheep breeds run by a university (Perezgrovas 2001). The rights of the Tzotzil people over the local sheep breeds have been maintained in the following way:

- the nucleus flock was founded from the local population and is managed in respect of local customs;

- representatives of the Tzotzil shepherdesses make all the breeding and culling decisions;

- Tzotzil communities get first choice of the progeny of the nucleus flock.

Demonstrable genetic gain has been achieved in the traits prioritized by the local people and a high demand for rams produced by the program is evident from Tzotzil communities (Perezgrovas 2001). 


\section{FINAL REMARKS}

Poor people's reliance on AnGR confers upon these resources a value of endowment as they enable wider choices of livelihood activities. The option values of adaptive AnGR stewarded by the poor are also significant for society. In part, the option values are maintained through traditional husbandry in marginal and often harsh environments. This is a service poor livestock keepers provide to society.

Collective action for the management of AnGR by the poor is only possible where the genetic resource is central to livelihoods in cultural and/ or socio-economic terms. The way such collective action is organized (in terms of equity of access, exclusivity of benefit distribution etc.) depends not only on the characteristics of the local AnGR ownership rights, but also on the access to rights over the common property resources required for animal production. Property rights rules in use for those resources complementary to livestock production are often complex and reciprocal, among different stakeholders. Customary practices of animal husbandry central to the management of AnGR are at risk and in some cases are breaking down in the face of external factors that are also marginalizing livestock keepers.

Processes for the maintenance of local institutions of AnGR management are required that allow the development of markets and the provision of incentives for the conservation of the option values of AnGR managed by the poor. Local property right systems need to be taken into account and respected (where possible through integration) in the development of national legislation for AnGR management.

Sustainable AnGR management regimes should provide the means whereby local, national and international property rights systems are integrated to provide security of 
assets for the poor and processes of benefit sharing from the maintenance and realisation of the option values of AnGR managed by the poor. A process of negotiation over AnGR property rights is required between the sets of actors currently involved in managing AnGR of likely high option value (often poor livestock keepers) and those investing in the biotechnology necessary to exploit those option values. 


\section{REFERENCES}

Agrawal, A. 1992. The grass is greener on the other side: A study of Raikas, migrants pastoralist of Rajasthan. IIED Drylands Issue Paper n.36. London: International Institute for Environment and Development.

Agrawal, A. 1999. Greener pastures: Politics, markets, and community among a migrant pastoral people. Durham, NC: Duke University Press and New Delhi: Oxford University Press.

Anderson, S. 2003. Animal genetic resources and livelihoods. Ecological Economics 45 (3), 331-339.

Anderson, S. 2004. Environmental effects on animal genetic resources. Review for the FAO AGAP. Rome: FAO.

http://www.fao.org/ag/cgrfa/docs.htm\#bspftp://ext-ftp.fao.org/ag/cgrfa/BSP/bsp28e.pdf

Anderson, S., S. Clark, B. Keane, J. Mogel Pliego, and W. Trejo Diaz. 2002. ParcelaSolar: an experience in combining campesino and conventional experimentation. Final Technical Report to the Livestock Production Programme, London: DFID.

Blackburn, H., S.H.B. Lebbie, and A.J. van der Zijpp, A. J. 1998. Animal genetic resources and sustainable development. Paper presented at the 6th World Congress on Genetics Applied to Livestock Production, Armidale Australia.

Bromley, D. 1991. Environment and economics: property rights and public policy. Cambridge, Mass., USA: Blackwell.

Bromley, D.W. and M.M. Cernea. 1989. The management of common property natural resources: some conceptual and operational fallacies. World Bank Discussion Paper No. 57. Washington, D.C.: World Bank.

Bromley, D. and E. Sjiaastad. 2000. The prejudices of property rights: on individualism specificity and security in property regimes. Development Policy Review 18 (4):365-389.

Centonze, R. 2003. Dialectical relationships in property rights for natural resources. Unpublished Master Special Study, Dept. Agricultural Sciences, Imperial College of London, London.

Demsetz, H. 1967. Toward a theory of property rights. American Economic Review 57 (2): 347-349.

Dorward, A. 2005 Understanding small stock as livelihoods assets. Final Technical Report. http://uploads.vli.co.uk/lpp/disseminations/R7823/R7823\%20FTR.pdf 
Drucker, A., Gomez, V., \& Anderson, S. 2001. The economic valuation of farm animal genetic resources: a survey of available methods. Ecological Economics 36 (1): 1-18 http://www.elsevier.nl/cas/tree/store/ecolec/sub/2001/36/1/1163.pdf

Dutfield, G. 2000. Intellectual property rights, trade and biodiversity. London: Earthscan Publications.

FAO. 2000. World Watch list for domestic animal diversity (3rd. ed.). Rome: FAO.

Geerlings, E.C.L. 2001. Sheep husbandry and ethnoveterinary knowledge of Raika sheep pastoralists in Rajasthan, India. Master Thesis, Wageningen University, Deventer, The Netherlands. Published on the web http://www.pastoralpeoples.org/docs/eg02abstractcontents.pdf

Government of India, 1974. Forest Act. New Delhi, India.

Hall, S. J. G. and J. Ruane. 1993. Livestock breeds and their conservation - a global review. Conservation Biology 7 (4): 815-825.

Henson, E. L. 1992. In situ conservation of livestock and poultry. Animal Production and Health Paper No. 99. Rome: FAO.

Knox, A., R.S. Meinzen-Dick, and P.R. Hazell. 2001. Property rights, collective action, and technologies for natural resource management: a conceptual framework. In Innovation in natural resource management: The role of property rights and collective action, ed. Meinzen-Dick, R.S., A. Knox, F. Place \& B.M. Swallow. Washington DC: Johns Hopkins University Press.

Meinzen-Dick, R. S. and R. Pradhan. 2002. Legal pluralism and dynamic property rights. CAPRi Working Paper No.22. Washington DC: International Food Policy Research Institute. http://www.capri.cgiar.org/pubs/capriwp01.pdf

Mendelsohn, R. 2005. The challenge of conserving indigenous domesticated animals. Ecological Economics, 45 (3): 501-510.

Norgaard, R.B. 1994. Development betrayed: The end of progress and a co-evolutionary revisioning of the future. London and New York: Routledge.

Olson, M. 1965. The logic of collective action. Cambridge, Mass, USA: Harward University Press.

Ostrom, E. 1990. Governing the commons, the evolution of institutions for collective action. Cambridge: Cambridge University Press. 
Ostrom, E. 1985. Formulating the elements of institutional analysis. Paper presented at the Conference on Institutional Analysis and Development, Washington, D.C., May 2122. http://dlc.dlib.indiana.edu-documents-dir0-00-00-07-38-dlc-00000738-00EOFO85AA.pdf

Ostrom, E., R. Gardner, and J. Walker. 1994. Rules, games, and common-pool resources. Ann Arbor: The University of Michigan Press.

Pearce, D. and D. Moran. 1994. The economic value of biodiversity. London: Earthscan.

Perezgrovas, R. 2001. Validation of indigenous technical knowledge as the basis for in improvement of sustainable livelihoods in Tzotzil villages, Chiapas, Mexico. PhD Thesis. Imperial College at Wye, University of London, London.

Rathore, S.H. and I. Köhler-Rollefson. 2001. Indigenous institutions for managing livestock genetic diversity in Rajasthan (India). In Experiences in farmer's biodiversity management. Report of the International Workshop on Animal and Plant genetic Resources in Agricutlrue at the Biosphere Reserve Schorheide-Chorin, Germany 16-18 May, 2000. Forum Umwelt und Entwicklung, Bonn, Germany.

Robbins, P. 2000. The rotten institution: Corruption in natural resource management. Political Geography 19 (4) 423-443.

Sen A. 1987. Hunger and entitlements. WIDER Research for Action. Helsinki, Finland: World Institute for Development Economics Research, United Nations University.

The Crucible II Group, 2002. Seedling solutions: Vol. 2. Options for national laws governing control over genetic resources and biological innovations. Ottawa: International Development Research Centre.

van der Zijpp, A.J. (nd). Ecological and economic perspectives in global animal agriculture. http://citeseer.ist.psu.edu/353249.html, accessed January 2003.

Wade, R. 1988. Village republics. Cambridge: Cambridge University Press.

Wang, N. 2001. The co-evolution of institutions, organizations, and ideology: the longlake experience of property rights transformation. Chicago: University of Chicago. http://www.isnie.org/ISNIE01/Papers01/wang.pdf 


\section{List of CAPRi Working Papers}

01 Property Rights, Collective Action and Technologies for Natural Resource Management: A Conceptual Framework, by Anna Knox, Ruth Meinzen-Dick, and Peter Hazell, October 1998.

02 Assessing the Relationships between Property Rights and Technology Adoption in Smallholder Agriculture: A Review of Issues and Empirical Methods, by Frank Place and Brent Swallow, April 2000.

03 Impact of Land Tenure and Socioeconomic Factors on Mountain Terrace Maintenance in Yemen, by A. Aw-Hassan, M. Alsanabani and A. Bamatraf, July 2000 .

04 Land Tenurial Systems and the Adoption of a Mucuna Planted Fallow in the Derived Savannas of West Africa, by Victor M. Manyong and Victorin A. Houndékon, July 2000.

05 Collective Action in Space: Assessing How Collective Action Varies Across an African Landscape, by Brent M. Swallow, Justine Wangila, Woudyalew Mulatu, Onyango Okello, and Nancy McCarthy, July 2000.

06 Land Tenure and the Adoption of Agricultural Technology in Haiti, by Glenn R. Smucker, T. Anderson White, and Michael Bannister, October 2000.

07 Collective Action in Ant Control, by Helle Munk Ravnborg, Ana Milena de la Cruz, María Del Pilar Guerrero, and Olaf Westermann, October 2000.

08 CAPRi Technical Workshop on Watershed Management Institutions: A Summary Paper, by Anna Knox and Subodh Gupta, October 2000.

09 The Role of Tenure in the Management of Trees at the Community Level: Theoretical and Empirical Analyses from Uganda and Malawi, by Frank Place and Keijiro Otsuka November 2000.

10 Collective Action and the Intensification of Cattle-Feeding Techniques a Village Case Study in Kenya's Coast Province, by Kimberly Swallow, November 2000.

11 Collective Action, Property Rights, and Devolution of Natural Resource Management: Exchange of Knowledge and Implications for Policy, by Anna Knox and Ruth Meinzen-Dick, January 2001. 
12 Land Dispute Resolution in Mozambique: Evidence and Institutions of Agroforestry Technology Adoption, by John Unruh, January 2001.

13 Between Market Failure, Policy Failure, and "Community Failure": Property Rights, Crop-Livestock Conflicts and the Adoption of Sustainable Land Use Practices in the Dry Area of Sri Lanka, by Regina Birner and Hasantha Gunaweera, March 2001.

14 Land Inheritance and Schooling in Matrilineal Societies: Evidence from Sumatra, by Agnes Quisumbing and Keijuro Otsuka, May 2001.

15 Tribes, State, and Technology Adoption in Arid Land Management, Syria, by Rae, J, Arab, G., Nordblom, T., Jani, K., and Gintzburger, G., June 2001.

16 The Effects of Scales, Flows, and Filters on Property Rights and Collective Action in Watershed Management, by Brent M. Swallow, Dennis P. Garrity, and Meine van Noordwijk, July 2001.

17 Evaluating Watershed Management Projects, by John Kerr and Kimberly Chung, August 2001.

18 Rethinking Rehabilitation: Socio-Ecology of Tanks and Water Harvesting in Rajasthan, North-West India, by Tushaar Shah and K.V.Raju, September 2001.

19 User Participation in Watershed Management and Research, by Nancy Johnson, Helle Munk Ravnborg, Olaf Westermann, and Kirsten Probst, September 2001.

20 Collective Action for Water Harvesting Irrigation in the Lerman-Chapala Basin, Mexico, by Christopher A. Scott and Paul Silva-Ochoa, October 2001.

21 Land Redistribution, Tenure Insecurity, and Intensity of Production: A Study of Farm Households in Southern Ethiopia, by Stein Holden and Hailu Yohannes, October 2001.

22 Legal Pluralism and Dynamic Property Rights, by Ruth Meinzen-Dick and Rajendra Pradhan, January 2002.

23 International Conference on Policy and Institutional Options for the Management of Rangelands in Dry Areas, by Tidiane Ngaido, Nancy McCarthy, and Monica Di Gregorio, January 2002.

24 Climatic Variablity and Cooperation in Rangeland Management: A Case Study From Niger, by Nancy McCarthy and Jean-Paul Vanderlinden, September 2002. 
25 Assessing the Factors Underlying the Differences in Group Performance: Methodological Issues and Empirical Findings from the Highlands of Central Kenya, by Frank Place, Gatarwa Kariuki, Justine Wangila, Patti Kristjanson, Adolf Makauki, and Jessica Ndubi, November 2002.

26 The Importance of Social Capital in Colombian Rural Agro-Enterprises, by Nancy Johnson, Ruth Suarez, and Mark Lundy, November 2002.

27 Cooperation, Collective Action and Natural Resources Management in Burkina Faso: A Methodological Note, by Nancy McCarthy, Céline Dutilly-Diané, and Boureima Drabo, December 2002.

28 Understanding, Measuring and Utilizing Social Capital: Clarifying Concepts and Presenting a Field Application from India, by Anirudh Krishna, January 2003.

29 In Pursuit Of Comparable Concepts and Data, about Collective Action, by Amy Poteete And Elinor Ostrom, March 2003.

30 Methods of Consensus Building for Community Based Fisheries Management in Bangladesh and the Mekong Delta, by Parvin Sultana and Paul Thompson, May 2003.

31 Formal and Informal Systems in Support of Farmer Management of Agrobiodiversity: Some Policy Challenges to Consolidate Lessons Learned, by Marie Byström, March 2004.

32 What Do People Bring Into the Game: Experiments in the Field About Cooperation in the Commons, by Juan-Camilo Cárdenas and Elinor Ostrom, June 2004.

33 Methods for Studying Collective Action in Rural Development, by Ruth Meinzen-Dick, Monica Di Gregorio, and Nancy McCarthy, July 2004.

34 The Relationship between Collective Action and Intensification of Livestock Production: The Case of Northeastern Burkina Faso, by Nancy McCarthy, August 2004.

35 The Transformation of Property Rights in Kenya's Maasailand: Triggers and Motivations by Esther Mwangi, January 2005.

36 Farmers' Rights and Protection of Traditional Agricultural Knowledge, by Stephen B. Brush, January 2005. 
37 Between Conservationism, Eco-Populism and Developmentalism - Discourses in Biodiversity Policy in Thailand and Indonesia, by Heidi Wittmer and Regina Birner, January 2005.

38 Collective Action for the Conservation of On-Farm Genetic Diversity in a Center of Crop Diversity: An Assessment of the Role of Traditional Farmers' Networks, by Lone B. Badstue, Mauricio R. Bellon, Julien Berthaud, Alejandro Ramírez, Dagoberto Flores, Xóchitl Juárez, and Fabiola Ramírez, May 2005.

39 Institutional Innovations Towards Gender Equity in Agrobiodiversity Management: Collective Action in Kerala, South India,, by Martina Aruna Padmanabhan, June 2005.

40 The Voracious Appetites of Public versus Private Property: A View of Intellectual Property and Biodiversity from Legal Pluralism, by Melanie G. Wiber, July 2005.

41 Who Knows, Who Cares? Determinants of Enactment, Awareness and Compliance with Community Natural Resource Management Bylaws in Uganda, by Ephraim Nkonya, John Pender, Edward Kato, Samuel Mugarura, and James Muwonge, August 2005.

42 Localizing Demand and Supply of Environmental Services: Interactions with Property Rights, Collective Action and the Welfare of the Poor, by Brent Swallow, Ruth Meinzen-Dick, and Meine von Noordjwik, September 2005.

43 Initiatives for Rural Development through Collective Action: The Case of Household Participation in Group Activities in the Highlands of Central Kenya, By Gatarwa Kariuki and Frank Place, September 2005.

$44 \quad$ Are There Customary Rights to Plants? An Inquiry among the Baganda (Uganda), with Special Attention to Gender, by Patricia L. Howard and Gorettie Nabanoga, October 2005.

45 On Protecting Farmers' New Varieties: New Approaches to Rights on Collective Innovations in Plant Genetic Resources by Rene Salazar, Niels P. Louwaars, and Bert Visser, January 2006.

46 Subdividing the Commons: The Politics of Property Rights Transformation in Kenya's Maasailand, by Esther Mwangi, January 2006.

47 Biting the Bullet: How to Secure Access to Drylands Resources for Multiple Users, by Esther Mwangi and Stephan Dohrn, January 2006. 